\title{
RANCANG BANGUN KENDARAAN LISTRIK
}

\author{
Zilman Syarif ${ }^{1}$, Mochammad Ali ${ }^{2}$, Aris Sumule ${ }^{3}$
}

\begin{abstract}
Abstrak :
Sinar matahari yang sangat melimpah di Nusa Tenggara Timur (NTT), memiliki dampak yang dirasakan di perairan NTT adalah suhu dan temperatur udara pada siang hari mencapai 34 derajat celsius, suhu panas sangat dirasakan terutama di Kupang, pada siang hari tepat pukul 12.00 WITA, temperatur udara di sebagian besar wilayah NTT seperti Kupang dan sekitarnya mencapai 34 derajat Celsius. Kondisi tersebut berbeda dengan hari-hari biasanya di mana temperatur minimum NTT 32-33 derajat Celsius, kondisi alam ini (suhu naik hingga 3435 derajat celsius) terjadi karena matahari berada di titik kulminasi atau tepat di atas Kota Kupang.

Kondisi suhu panas yang dirasakan di Kupang selama ini dapat dimanfaatkan sebagai pembangkit tenaga listrik, hal ini telah dibuktikan oleh Pemerintah Kota (Pemko) Kupang Nusa Tenggara Timur (NTT) yaitu dengan memanfaatkan solar cell untuk lampu jalan yang terbukti mampu menghemat pembayaran tagihan listrik untuk lampu jalan sebesar Rp. 1 miliar per bulan. Penghematan ini diperoleh setelah dipasang 541 unit lampu jalan di Kupang dengan menggunakan panel surya dari jenis lampu LED (laigth emmiting diode) dengan daya 23-35 watt .(detikfinance, 14/6/2011).

Kendaraan Motor Listrik yang dijalankan dengan tenaga listrik DC (direct current) menggunakan accu (baterai) sebagai sumbernya yang diperoleh dari hasil pengisian melalui listrik AC (alternating current) yang telah disearahkan dan atau dari panel surya (Solar Cell) atau tenaga matahari. Panel surya merupakan komponen yang sangat penting karena dapat mengubah sinar matahari menjadi energi listrik yang kemudian disimpan di dalam baterai. Selanjutnya digunakan untuk menggerakkan motor DC yang terhubung dengan sistem penggerak roda berupa kombinasi geer, sistem penggerak ini akan memberikan daya gerak yang menggerakkan kendaraan solar cel ini yang bergantung pada beberapa hal seperti kecepatan motor, putaran penggerak, berat kendaraan dan lain-lain.

Tujuan jangka panjangnya adalah: 1) Untuk menyediakan kendaraan yang tidak memerlukan bahan bakar minyak dan bersih dari polusi karena menggunakan listrik DC dan tenaga matahari melimpah di NTT terutama untuk kendaraan yang dapat diantar-pulaukan mengingat NTT terdiri dari pulau-pulau kecil dan besar dan tidak semua pulau memiliki pangkalan bahan bakar minyak; 2) Aplikasi penggunaan panel solar cell dapat dikembangkan lagi seperti untuk pengairan pada lahan yang kesulitan air dimusim kemarau yaitu dengan membuat pompa air bertenaga matahari dan kemanfaatan lainya.

Tujuan Khusus :

Berdasarkan fenomena di atas, maka tujuan khusus dari penelitian ini adalah : 1) Untuk membuat model Kendaraan Motor Listrik (kendaraan) dengan tenaga solar cell; 2) Untuk merancang penggunaan solar cell sebagai sumber daya untuk Kendaraan Motor Listrik DC; 3) Untuk mengevaluasi penggunaan motor dan sistim geer yang sesuai dan aman.
\end{abstract}

Syarif $^{1}$, Ali $^{2}$, Adalah Dosen Teknik Elektro, Politeknik Negeri Kupang 


\section{Jurnal Ilmiah FLASH Volume 2 Nomor 2 Desember 2016}

Untuk mencapai tujuan penelitian, dilakukan penelitian secara bertahap selama 2 (dua) tahun dengan rincian sebagai berikut :

Tahun I : Perancangan Kendaraan Motor Listrik (Kendaraan) dengan tenaga listrik DC (direct current) dan sistem transmisi geer mekanik. Penelitian Tahun I terdiri dari dua tahap, yaitu Tahap (1) Perancangan dan pembuatan rangka Kendaraan Motor Listrik dengan penggerak mekanik dan motor listrik DC. Dan Tahap (2) Uji kelayakan jalan (jarak tempuh) dan kecepatan serta kemampuan motor DC Pada Penelitian Tahap I Dengan sistem pengaturan kecepatan.

Tahun II : Perancangan Kendaraan Motor Listrik (Kendaraan) dengan tenaga listrik DC (direct current) dari Solar Cell dan penyesuaian sistem transmisi geer mekanik. Penelitian Tahun II juga terdiri dari dua tahap, yaitu Tahap (1) Perancangan dan pemasangan Solar Cell rangka Kendaraan Motor Listrik dengan penggerak mekanik yang disesuaikan dengan sistem transmisi geer mekanik terhadap motor listrik DC yang digunakan. Dan Tahap (2) Uji kelayakan jalan (jarak tempuh) dan kecepatan serta kemampuan motor DC dengan sumber Solar Cell Pada Penelitian Tahap I Dengan menggunakan sistem pengaturan kecepatan.

Kata-kata Kunci : Splar Cell, Motor Listrik BLDC, Solar Cell.

\section{PENDAHULUAN}

Badan Meteorologi, Klimatologi, dan Geofisika Stasiun Lasiana Kupang memprediksikan suhu panas yang tahun ini melanda daerah setempat dengan tekanan maksimal mencapai 35 derajat celcius. Kondisi cuaca seperti suhu panas akibat musim kemarau ini wajar terjadi. Hal ini sesuai dengan karakteristik daerah setempat yang tandus serta berada di kawasan pantai yang umumnya memiliki suhu panas, terkait cuaca ekstrem berupa suhu panas yang kini dirasakan sebagian besar warga NTT sejak Juni dan memuncak diakhir Oktober.

Dampak yang dirasakan di perairan NTT adalah suhu dan temperatur udara pada siang hari mencapai 34 derajat celsius, suhu panas sangat dirasakan terutama di Kupang, pada siang hari tepat pukul 12.00 WITA, temperatur udara di sebagian besar wilayah NTT seperti Kupang dan sekitarnya mencapai 34 derajat Celsius. Kondisi tersebut berbeda dengan hari-hari biasanya di mana temperatur minimum NTT 3233 derajat Celsius, kondisi alam ini (suhu naik hingga 34-35 derajat celsius) terjadi karena matahari berada di titik kulminasi atau tepat di atas Kota Kupang.

Kondisi suhu panas yang dirasakan di Kupang selama ini dapat dimanfaatkan sebagai pembangkit tenaga listrik, hal ini telah dibuktikan oleh Pemerintah Kota (Pemkot)
Kupang Nusa Tenggara Timur (NTT) yaitu dengan memanfaatkan solar cell untuk lampu jalan yang terbukti mampu menghemat pembayaran tagihan listrik untuk lampu jalan sebesar Rp.1 miliar per bulan. Penghematan ini diperoleh setelah dipasang 541 unit lampu jalan di Kupang dengan menggunakan panel surya dari jenis lampu LED (laigth emmiting diode) dengan daya 23-35 watt .(detikfinance, 14/6/ 2011).

Berdasarkan pemikiran di atas yaitu memanfaatkan sinar matahari sebagai pembangkit tenaga listrik dan kondisi daerah NTT yang selalu mengalami musim panas yang panjang berkisar 9 sampai dengan 10 bulan setiap tahun maka kemanfaatan yang lain adalah menggunakan energi matahari tersebut sebagai tenaga untuk penggerak Kendaraan Motor Listrik dengan memodifikasi dan merancangnya.

Akan tetapi ada banyak hal yang harus diketahui tentang pembuatan Kendaraan Motor Listrik bertenaga listrik dan pemanfaatan panel solar cell seperti motor, geer, control kecepatan, regulator tegangan, inverter dan masih banyak lagi yang memerlukan spesifikasi perhitungan dan teori agar dapat berfungsi dengan benar hal ini dikarenakan tidak ada panel solar cell yang sesuai untuk menggerakkan Kendaraan Motor Listrik bertenaga listrik oleh karena itu penelitian ini menitik beratkan pada sistem control kecepatan penggerak Kendaraan Motor Listrik 
bertenaga listrik dan pemanfaatan panel solar cell sehingga dapat bekerja atau tidak, dengan demikian pokok pikiran yang mendasarinya adalah bagaimana mengembangkan/merancang bentuk Kendaraan Motor Listrik, sistem kelistrikan, sistem mekanik, sistem control kecepatan dan rancangan panel solar cell dan faktor-faktor lain yang menjadi bahan pertimbangan seperti; effisiensi, biaya, berat kendaraan, dan keselarasan sistem yang bekerja.

Faktor-faktor tersebut sangat penting karena akan berpengaruh dalam sistem rancangan yang baik secara keseluruhan sebagai contoh apakah sistem geer yang digunakan sangat effisien terhadap berat dari kendaraan keseluruhan, apakah biaya dan waktu yang diperlukan cukup untuk menyelesaikan penelitian, sehingga diperlukan alternafi-alternatif yang lain.

\section{TINJAUAN PUSTAKA}

Sistem Manajemen Basis data adalah suatu metode untuk pengelolaan dan penyimpanan informasi skala besar, yaitu informasi dengan kapasitas besar dan banyak ragam yang meliputi fungsi perlindungan atas kesatuan data, mendukung perawatan yang mudah, menangani queryquery, mempertahankan akses yang ampuh, dan menjamin keamanan data demikian Bukhres (Handoyo, 2003).

Dari beberapa referensi terangkum beberapa difinisi yang saling melengkapi untuk membantu pemahaman dari materi penelitian ini diantaranya adalah Sistem Pengelola Basis Data (Data base management System/ DBMS).

Pengelolaan basis data secara fisik tidak dilakukan oleh pemakai secara langsung, tetapi ditangani oleh sebuah Perangkat Lunak (Sistem) yang khusus/spesifik. Perangkat lunak ini (disebut DBMS) yang akan menentukan bagaimana data diorganisasi, disimpan, dirubah dan diambil kembali.

Sistem tersebut juga menerapkan mekanisme pengamanan data, pemakaian data secara bersama, pemaksaan keakuratan/konsistensi data, dan sebagainya.
DBMS merupakan salah satu elemen dalam sistem basis data, yang merupakan perangkat lunak yang memberikan fasilitas (yang tersedia dan dapat digunakan) untuk melakukan fungsi pengaturan, pengawasan, pengendalian/kontrol, pengolahan dan koordinasi terhadap semua proses/operasi yang terjadi pada system basis data berorientasi objek.

Proses mendesain basis data dengan baik merupakan salah satu hal penting yang perlu diperhatikan dalam menunjang keberhasilan pemakaian suatu aplikasi. Desain basis data yang baik dan efektif harus memperhatikan user requirement dan sifat data yang diakses oleh aplikasi yang bersangkutan, demikian (Sukmana, 2002) mengungkapkan dalam tesisnya yang berjudul "Desain dan implementasi basis data multidimensi untuk pengembangan aplikasi pemantauan biaya (Studi Kasus: PT ARCO)".

Dijelaskan pula bahwa untuk dapat memenuhi kebutuhan proses multi level dan agregasi multidimensional, multidimensional analytical calculation, serta ad hoc review reorganizations Thomsen (Sukmana, 2002), diperlukan adanya desain basis data baru yang sesuai dengan sifat aplikasi yang dimaksud berupa desain basis data yang dapat mendukung teknologi multidemensi tersebut, dikarenakan aplikasi yang lebih bersifat query intensif yang banyak terjadi pada proses groping dan rollup untuk menghasilkan data agregasi, pada aplikasi tersebut juga mengakses struktur data yang lebih bersifat multidimensi dari pada relasional.

Hal yang senada dikatakan oleh Ilhamsyah (2002) dalam tesisnya "Perencanaan Sistem Informasi Rumah Sakit Umum Pusat Nasional Dr. Cipto Mangunkusumo", basis data dengan menggunakan relational database memiliki through Out, scalability, dan availability yang tinggi.

Data ditempatkan secara terpusat dan dapat diakses oleh pengguna secara remote oleh pengguna dengan menggunakan browser, maksudnya dipergunakannya teknologi webbased application. Hasilnya adalah sistem yang direncanakan meningkatkan kualitas pelayanan 


\section{\begin{tabular}{l|llll}
62 & Jurnal Ilmiah $F L A S H$ & Volume 2 & Nomor 2 & Desember 2016
\end{tabular}}

terhadap pasien. Selain itu SI/TI juga dapat meningkatkan produktifitas setiap pegawainya.

Di dalam dunia pendidikan, dengan adanya kebijakan pemerintah untuk menerapkan otonomi perguruan tinggi, maka perguruan tinggi tersebut dituntut untuk mandiri dalam penyelenggaraan kegiatannya.

Perjalanan menuju otonomi perguruan tinggi akan menghadapkan setiap perguruan tinggi pada restrukturisasi yang substansial, mulai dari visi, misi, manajemen, hingga cara melakukan dan mengevaluasi proses-proses yang mendukungnya. Pendekatan terhadap rancangan dapat dilakukan dari dua sisi, yaitu dari sisi proses dan dari sisi pengguna.

Dari sisi proses sistem informasi harus dapat mendukung setiap proses yang terjadi dalam kegiatan manajemen Sumber Daya Manusia. Dari sisi pengguna, sistem informasi harus bisa memberikan informasi yang dibutuhkan oleh pengguna dengan mudah, cepat dan akurat. Rancangan sistem informasi juga mempertimbangkan kemajuan dan tren teknologi, terutama perkembangan teknologi internet (Evianti, 2002).

\subsection{Landasan Teori}

Pembangkit Listrik Tenaga Surya (PLTS) adalah pembangkit yang memanfaatkan sinar matahari sebagai sumber penghasil listrik. Alat utama untuk menangkap, merubah dan menghasilkan energi listrik adalah fotovoltaik atau yang disebut secara umum Modul / Panel sel surya. Dengan alat tersebut sinar matahari dirubah menjadi listrik melalui proses aliranaliran elektron negatif dan positif didalam sel modul tersebut karena perbedaan elektron. Hasil dari aliran elektron-elektron akan menjadi listrik DC yang dapat langsung dimanfaatkan untuk mengisi battery / aki sesuai tegangan dan ampere yang diperlukan. Rata-rata produk modul sel surya yang ada dipasaran menghasilkan tegangan $12 \mathrm{~s} / \mathrm{d} 18 \mathrm{VDC}$ dan ampere antara 0.5 s/d 7 Ampere. Modul juga memiliki tipe sel monocrystal dan polycrystal. Komponenkomponen dari sistem PLTS ini meliputi per- alatan : Modul Sel surya, Regulator/controller, Battery/Aki, Inverter DC to AC, Beban/Load.

Komponen inti dalam pembangkit listrik ini adalah sel surya. Sel surya adalah suatu komponen elektronika yang dapat mengubah energi surya menjadi energi listrik dalam bentuk arus searah (DC). Modul surya (fotovoltaik) adalah sejumlah sel surya yang dirangkai secara seri dan paralel, untuk meningkatkan tegangan dan arus yang dihasilkan sehingga cukup untuk pemakaian sistem catu daya beban.Untuk mendapatkan keluaran energi listrik yang maksimum maka permukaan modul surya harus selalu mengarah ke matahari. Di Indonesia, energi listrik yang optimum akan di dapat apabila modul surya diarahkan dengan sudut kemiringan sebesar lintang lokasi PLTS tersebut berada. Sebagai contoh, untuk daerah yang berada di sebelah utara kathulistiwa maka modul surya harus dihadapkan ke Selatan, dan sebaliknya. Selanjutnya energi listrik tersebut disimpan dalam Baterai. Baterai disini berfungsi sebagai penyimpan energi listrik secara kimiawi pada siang hari dan berfungsi sebagai catu daya listrik pada malam hari. Untuk menjaga kesetimbangan energi di dalam baterai, diperlukan alat pengatur elektronik yang disebut Battery Charge Regulator (BCR). Alat ini berfungsi untuk mengatur tegangan maksimal dan minimal dari baterai dan memberikan pengamanan terhadap sistem, yaitu; Proteksi terhadap pengisian berlebih (over charged) oleh penyinaran matahari, pemakaian berlebih oleh beban, mencegah terjadinya arus balik ke modul surya, melindungi terjadinya hubung singkat pada beban listrik dan sebagai interkoneksi dari komponen-komponen lainnya.

Sel surya dapat menghasilkan energi listrik dalam jumlah yang tidak terbatas langsung diambil dari matahari, tanpa ada bagian yang berputar dan tidak memerlukan bahan bakar. Sehingga sistem sel surya sering dikatakan bersih dan ramah lingkungan. Bandingkan dengan sebuah generator listrik, ada bagian yang berputar dan memerlukan bahan bakar untuk dapat menghasilkan listrik. Suaranya bising. Selain itu gas buang yang dihasilkan dapat 
menimbulkan efek gas rumah kaca (green house gas) yang pengaruhnya dapat merusak ekosistem planet bumi kita.

Pada tengah hari yang cerah radiasi sinar matahari mampu mencapai 1000 watt permeter persegi. Jika sebuah divais semikonductor seluas satu meter persegi memiliki efisiensi 10 persen maka modul solar sel ini mampu memberikan tenaga listrik sebesar 100 watt. Saat ini modul solar sel komersial berkisar antara 5 hingga 15 persen tergantung material penyusunnya. Tipe silikon kristal merupakan jenis divais solar sel yang memiliki efisiensi tinggi meskipun biaya pembuatannya relatif lebih mahal dibandingkan jenis solar sel lainnya. Pembangkit energi surya sebenarnya tergantung pada efisiensi mengkonversi energi dan konsentrasi sinar matahari yang masuk ke dalam sel tersebut. Professor Smalley, peraih Nobel bidang kimia atas prestasinya menemukan Fullerene, menyatakan bahwa teknologi nano menjanjikan peningkatan efisiensi dalam pembuatan sel surya antara 10 hingga 100 kali pada sel surya. Smalley menambahkan bahwa cara terbaik untuk mendapatkan energi surya secara optimal telah terbukti ketika sel surya dimanfaatkan untuk keperluan satelit ruang angkasa dan alat-alat yang diletakkan di ruang angkasa. Penggunaan sel surya dengan meletakkannya di ruang angkasa dapat dengan baik dilakukan karena teknologi nano diyakini akan mampu menciptakan material yang super kuat dan ringan yang mampu bertahan di ruang angkasa dengan efisiensi yang baik.

Perkembangan yang menarik dari teknologi sel surya saat ini salah satunya adalah sel surya yang dikembangkan oleh Michael Gratzel. Gratzel memperkenalkan tipe solar sel photokimia yang merupakan jenis solar sel exciton yang terdiri dari sebuah lapisan partikel nano (biasanya titanium dioksida) yang di endapkan dalam sebuah perendam (dye). Jenis ini pertama kali diperkenalkan pada tahun 1991 oleh Gratzel, sehingga jenis solar sel ini sering juga disebut dengan sel Gratzel atau dyesensitized solar cells (DSSC).
Sel Gratzel dilengkapi dengan pasangan redoks yang diletakkan dalam sebuah elektrolit (bisa berupa padat atau cairan). Komposisi penyusun solar sel seperti ini memungkinkan bahan baku pembuat sel Gratzel lebih fleksibel dan bisa dibuat dengan metode yang sangat sederhana seperti screen printing. Meskipun solar sel generasi ketiga ini masih memiliki masalah besar dalam hal efisiensi dan usia aktif sel yang masih terlalu singkat, solar sel jenis ini diperkirakan mampu memberi pengaruh besar dalam sepuluh tahun ke depan mengingat harga dan proses pembuatannya yang sangat murah.

Dalam kondisi puncak atau posisi matahari tegak lurus, sinar matahari yang jatuh di permukaan panel surya di Indonesia seluas satu meter persegi akan mampu mencapai 900 hingga 1.000 Watt. Total intensitas penyinaran perharinya di Indonesia mampu mencapai 4500 watt hour per meter persegi yang membuat Indonesia tergolong kaya sumber energi matahari ini. Dengan letaknya di daerah katulistiwa, matahari di Indonesia mampu bersinar hingga 2.000 jam pertahunnya. Dengan kondisi yang sangat potensial ini sudah saatnya pemerintah dan pihak universitas membuat satu pusat penelitian solar sel agar Indonesia tidak kembali hanya sebagai pembeli divais solar sel di tengah melimpahnya sinar matahari yang diterima di bumi Indonesia.

\subsection{Komponen-Komponen PLTS}

Adapun komponen-komponen pada suatu Pembangkit Listrik Tenaga Surya secara umum adalah sebagai berikut :

\section{1). Fotovoltaik (sel surya)}

Fotovoltaik berfungsi mengubah radiasi matahari menjadi listrik secara langsung (direct conversion). Modul fotovoltaik dirakit dari susunan sel surya atau sel fotovoltaik yang dirangkai secara seri atau paralel. Teknologi sel fotovoltaik yang banyak dikembangkan dewasa ini pada umumnya merupakan jenis teknologi kristal yang dibuat dengan bahan berbasis silikon. Produk akhir dari modul fotovoltaik menyerupai bentuk lembaran kaca dengan 
ketebalan sekitar 6-8 milimeter. Sinar matahari yang menimpa permukaan modul akan diubah secara langsung, tanpa adanya bagian yang bergerak, menjadi listrik sebagai akibat terjadinya pergerakan pasangan "elektron-hole" di dalamnya.

Teknologi fotovoltaik dikenal sebagai teknologi bersih sehingga penerapannya akan mendukung program pembangunan yang berwawasan dan bersahabat dengan lingkungan. Besar energi listrik yang dihasilkan oleh fotovoltaik tergantung pada intensitas radiasi matahari setempat. Besar energi matahari di Indonesia yang jatuh pada permukaan seluas satu meter persegi selama satu hari berkisar antara 4 - $6 \mathrm{kWh}$ (atau sering dinyatakan dengan satuan: $\mathrm{kWh} / \mathrm{m}^{2}$.hari). Energi listrik yang dihasilkan dari modul fotovoltaik berupa listrik arus searah (DC) yang dapat langsung di gunakan atau disimpan kedalam baterai untuk dipergunakan pada saat lain ketika diperlukan dalam kondisi tidak ada cahaya matahari (dalam cuaca mendung/malam hari). Sistem penyimpanan listrik menggunakan baterai dilengkapi dengan alat pengatur baterai yaitu Battery Charge Regulator (BCR). Apabila diperlukan dapat dilengkapi inverter DC/AC yang memungkinkan penggunaan peralatan arus listrik AC (seperti sistem PLN).

Pada gambar 1 memperlihatkan gambar sketsa sebuah sel surya. Proses pembuatannya dimulai dengan bahan silicon yang hampir 100\% murni. Untuk membentuk lapisan dasar dari sel ditambahkan boron dalam jumlah yang sangat kecil sekali pada waktu Kristal sedang dibentuk. Ini yang menghasilkan lapisan dasar dari sel tipe-N. Setelah lapisan tipe-P dibentuk, di umpamakan fosvor untuk membentuk lapisan dari sel tipe $-\mathrm{N}$ dengan demikian membentuk $\mathrm{P}-\mathrm{N}$ junction. Hubungan logam disediakan untuk kedua lapisan tipe- $\mathrm{P}$ dan tipe-N.

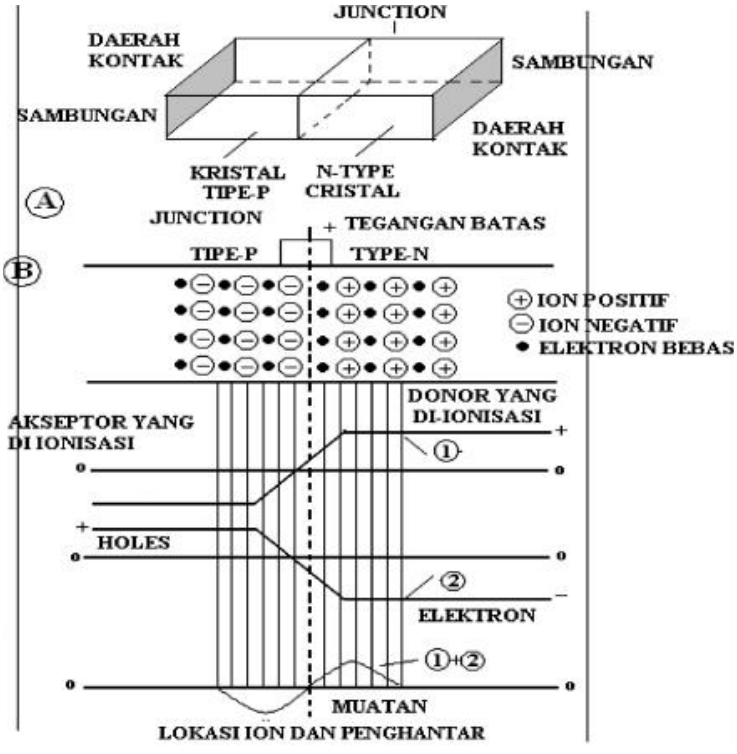

Gambar 1. Gambar sketsa sebuah sel surya

\section{2). Prinsip Kerja fotovoltaik (sel surya)}

Modul atau panel sel surya di jemur pada terik matahari maka semi konduktor P-N junction akan mengubah panas matahari menjadi tegangan listrik arus searah ( DC ). Tegangan yang dihasilkan sel surya di hubungkan ke regulator untuk pengisian baterai. Tegangan yang disimpan di baterai digunakan untuk keperluan beban yang menggunakan tegangan arus searah (DC). Jika beban yang dipakai adalah arus bolak-balik (AC) maka tegangan dari baterai disambungkan ke inverter untuk mengubah tegangan arus searah (DC) ke tegangan arus bolak balik (AC).

Untuk menurunkan tegangan pada sel surya maka sel-sel surya disusun secara pararel dan untuk menaikkan tegangan pada sel surya maka sel-sel surya disusun secara seri. Sistem keja dari fotovoltaik ( sel surya ) dapat dibagi menjadi beberapa sub sistem yakni seperti terlihat pada gambar 2. 


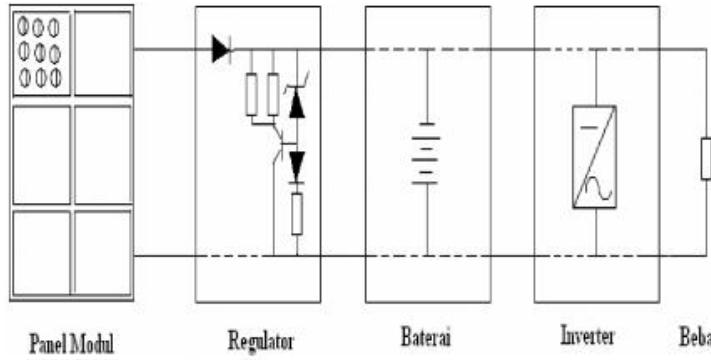

Gambar 2. Proses terjadinya fotovoltaik (sel surya)

Sumber : Sulasno, 1993

Collector (kolektor) sel surya

Terdiri dari modul atau array dan penyangga yang berfungsi untuk menerima dan mengubah energi surya menjadi listrik arus searah (DC).

Power conditioning (pengkondisi daya)

Terdiri dari :

- Kabel yang berfungsi untuk menghantarkan arus listrik.

- Regulator yang berfungsi untuk mengatur besarnya tegangan output dan memprodiksis sistem terutama baterai dari kerusakan karena overload beban maupun pengosongan atau pengisian berlebihan pada baterai.

- Baterai hanya digunakan memerlukan penyimpangan energi listrik seperti untuk beban penerangan. Bila tidak perlu, maka harus dihindari penggunaannya, karena selain harga dan perawatannya mahal. Sistem juga akan turun nilai efisiensinya. Baterai yang digunakan biasanya berbentuk accu (baterai) (sel basah).

- Inverter yang berfungsi mengubah listrik DC ke AC inventer digunakan bila beban menggunakan sistem AC. Inverter dapat berupa inverter tiga phasa dan inverter satu phasa disesuaikan dengan kebutuhan beban.

- Beban jenisnya macam-macam baik itu berupa barang elektronik maupun penerangan. Kebanyakan pada beban sistem sel surya lebih suka menyediakan sistem atau unit lengkap dari pada mematok sub sistem tersendiri.

\section{3). Sistem Sambungan Sel Surya}

Pada umumnya satu unit sel surya hanya mampu menghasilkan daya kecil. Daya yang di perbesar dapat di hasilkan dengan cara menghubung-hubungkan beberapa sel surya secara seri dan pararel. Susunan dari beberapa sel surya disebut modul dan beberapa modul menghasilkan array. Modul-modul dihubungkan seri dan parallel untuk mendapatkan karakteristik solar array yang diperlukan.

Dengan tanpa adanya bagian yang bergerak, maka modul dapat menghasilkan daya lebih dari 15 tahun. Dipasaran tersedia modul dari beberapa type semikonduktor (silicon) yaitu : a. Monokristal

Sel surya ini terbuat secara murni dari silicon yang mempunyai efisiensi yang paling tinggi dari type-type lainya, yakni $\pm 10-17 \%$. Pada umumnya sel ini berbentuk bulat.

b.Polikristal

Sel ini terbuat dari silikon tidak murni. Untuk membuat sel ini terbentuk mono Kristal, masih diperlukan proses lagi yang membutuhkan banyak biaya. Efesiensi dari sel polokristal ini berkisar antara 8-12\%. Sel ini biasanya bernentuk kotak-kotak.

\section{c. Amorphous}

Jenis ini dibuat dari logam yang dilapisi oleh lapisan tipis (beberapa astronom) silicon. Efisensi sel ini hanya mencapai 4-6\% pembuatan sel amorphous ditempuh dengan tujuan menurunkan biaya produksi. Selain efisensinya yang rendah, juga terdapat sifat degradation yang memperburuk sel ini.

Untuk sistem fotovoltaik yang berkapasitas besar harus disusun seri beberapa array. Letak masing-masing array harus diberi jarak dengan tidak saling terjadi timbul bayangan. Penempatan array diletakan diatas ring (penyangga) modul dengan ketinggian 1-2 meter diatas permukaan tanah hal ini bertujuan untuk:

a. Tidak tejadinya bayangan diatas modul sel surya yang ditimbulkan oleh rumput atau tanaman perdu.

b.Menghindari bahaya banjir.

c. Mempermudah dalam membersihkan gelas atau kaca modul sel surya. 


\section{4). Hubungan Seri dan Pararel Pada Modul Sel Surya}

Sel surya dapat dihubungkan seri dan pararel. Seperti diperlihatkan pada gambar 3, bila beberapa sel dihubungkan dalam seri, jumlah tegangan dari rakitan akan merupakan jumlah tegangan dari masing-masing sel arus output akan sama dengan sebuah sel tunggal. Bila sel-sel dihubungkan dalam pararel seperti yang diperlihatkan pada gambar 4 , jumlah arusnya adalah jumlah arus dari masing-masing sel, tetapi tegangannya akan sama dengan sebuah sel tunggal

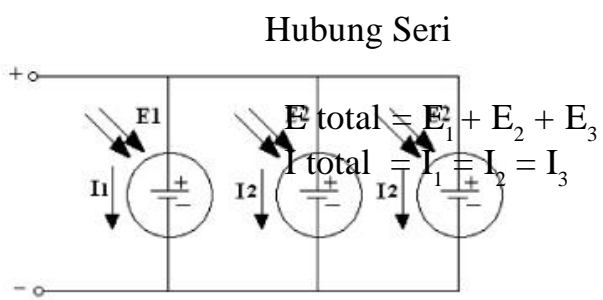

Gambar 3. Hubung Seri Sel Surya Sumber : Kadir A, 1995

$$
\begin{aligned}
& \mathrm{E} \text { total }=\mathrm{E}_{1}=\mathrm{E}_{2}=\mathrm{E}_{3} \\
& \mathrm{I} \text { total }=\mathrm{I}_{1}+\mathrm{I}_{2}+\mathrm{I}_{3}
\end{aligned}
$$

Gambar 4. Hubung pararell sel surya Sumber : Kadir A, 1995

Dalam kebanyakan aplikasi sel-sel dihubungkan dalam seri dan dalam pararel kedua-duanya ditunjukan pada gambar 5. Disini jumlah himpunan sel dalam seri akan menentukan tegangan dan jumlah sel dalam pararel dalam suatu himpunan akan menentukan arus yang diberikan pada beban.

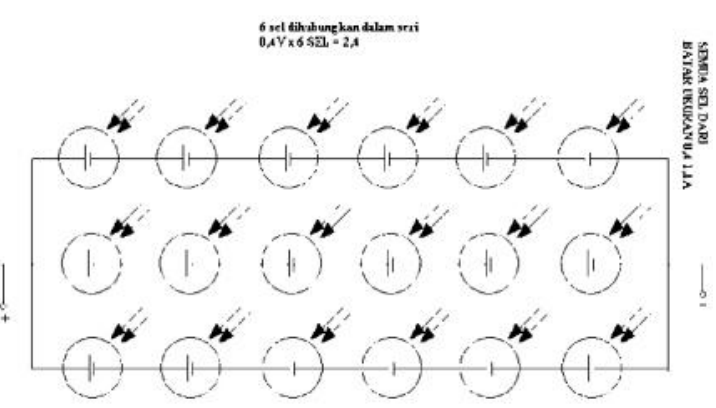

Gambar 5. Hubungan seri pararel sel surya untuk memberikan setiap batas ukur dengan tegangan dan arus. Sumber : Kadir A,1995

\section{5). Baterai Charger Regulator (BCR)}

Baterai Charger Regulator adalah komponen yang paling rumit dan sensitif. Meyakinkan pengoperasian sistem photovoltaic selalu stabil. Pengatur beban yang berlebihan dapat mengakibatkan kegagalan pemakaian dan mengakibatkan biaya pemeliharaan yang tinggi yang mencakup penggantian baterai. Suatu parameter penting untuk mempertimbangkan adalah persentase efisiensi pengaturan beban.

Ada beberapa jenis pengaturan beban yang berbeda yaitu tombol yang paling sederhana on/ off, dengan pengaturan baterai tegangan konstan atau arus tetap yang paling sering digunakan dalam pengaturan Photovoltaic. MPPT (Perkerjaan mengikuti jalan Titik Tenaga Maksimum) yang paling rumit. Pengaturan beban MPPT terjadi lebih mahal dan disesuaikan dengan sistem besaran yang lebih baik, dimana investasi dalam yang diatur meliputi semua peralatan elektronika untuk perlindungan baterei, seperti perlindungan terhadap kerusakan fungsi. Pengaturan beban adalah characterised oleh dua ambang pintu voltase berbeda, baterei dan voltase modul, dimana baterei dibebankan. Pada voltase lebih tinggi, pada umumnya $12 \mathrm{~V}$ sampai $12.4 \mathrm{~V}$, tombol pengatur beban kepada baterei pada voltase lebih rendah, secara khas $11.5 \mathrm{~V}$ pada tombol pengatur beban. 


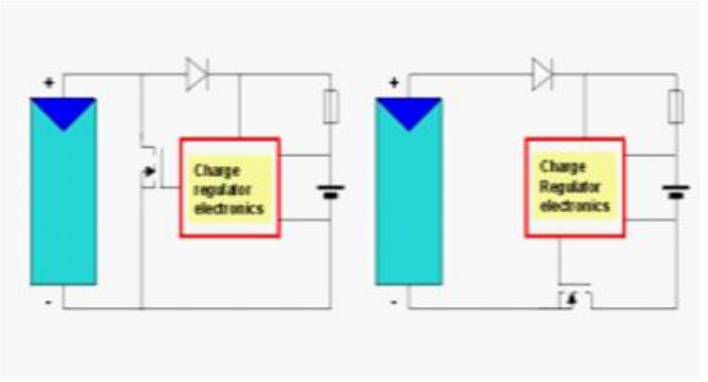

Gambar 6. Rangkaian Charger regulator Elektronik

Sumber : M. Gratzel, 2001

Energi matahari memproduksi sepanjang hari, yang dikonsumsi oleh beban dan disimpan oleh baterei. Energi yang disimpan dapat digunakan pada malam hari atau sepanjang hari dengan kondisi cuaca tidak baik. Baterei didalam sistem photovoltaic sering dicas oleh karena itu, baterai harus sesuai dengan kebutuhan (lebih kuat) dibanding baterei yang lain.

Ada banyak baterei matahari yang tersedia dipasaran, yang paling sering menggunakan $\mathrm{Pb}$ klasik, baterei asam diproduksi terutama untuk sistem photovoltaic dimana baterei magnetik, seperti Nicd atau Nimh jarang digunakan, kecuali jika alat jinjing. Hermetical Baterei terdiri dari asam aki, baterei tidak memerlukan pemeliharaan. Seumur hidup Baterei Sistem matahari khas bertahan hingga 3 sampai 5 tahun, tergantung dengan berat pada charging / discharging siklus, temperatur dan lain parameter.

\section{6). Acumulator (ACCU)}

Accu (baterai) merupakan sumber tegangan DC dimana accu mulator (baterai) adalah salah satu komponen yang mampu merubah energi kimia yang terdapat dalam bahan aktifnya secara langsung menjadi energi listrik dengan jalan reaksi elektrton kimia redok (Reduoksidasi).

Baterai mempunyai dua elektroda yaitu elektroda negatif dan elektroda positif. Elektroda negative adalah komponen yang mampu memberikan electron pada dioksidasi selama proses reaksi. Sedangkan elektroda positif adalah komponen yang mampu menerima elaktron pemindahan elektron-elektron terjadi pada rangkaian luar. Aliran elektron ini dapat diperoleh dengan jalan menghubungkan kedua terminal negatif dan positif melalui suatu beban. Cairan elektrolit dalam accu (baterai) tersebut bertindak sebagai pelengkap rangkaian yaitu sebagai tempat mengalirnya electron-elektron yang disebut dengan media "ionic".

Baterai adalah peralatan listrik yang mengubah tenaga kimia yang terkandung dalam bahan aktifnya secara langsung menjadi tenaga listrik, batterai hanya digunakan bila sistem memerlukan penyimpanan energi.

Baterai harus menyediakan daya kepada beban diwaktu tidak ada cahaya matahari dan harus pula meratakan perubahan-perubahan pada beban apa yang harus dilakukan oleh solar panel adalah untuk memenuhi persyaratan beban rata-rata sehari. Tentunya semua energi ini dibangkitkan pada siang hari, baterai akan menyimpan energi dan menyediakannya untuk beban bila diperlukan. Banyak tipe bateray yang berbeda-beda biasa didapatkan yang masingmasing memiliki kelebihan dan keterbatasan. Baterai biasanya diklasifikasikan kedalam dua tipe umum yaitu baterai primer dan sekunder baterai primer tidak dapat diisi lagi muatanya. Baterai sekunder adalah suatu baterai yang muatanya dapat diisi berulang kali

Baterai dikelompokan menjadi dua jenis yaitu accu (baterai) mulator primer dan Baterai sekunder. Baterai primer adalah Baterai yang sangat sulit diisi kembali secara listrik karena kosong setelah digunakan. Baterai yang paling umum digunakan adalah bateray jenis sekunder.

\section{7). Mekanik}

\section{a. Sistem Transmisi}

Sistem transmisi, dalam otomotif, adalah sistem yang berfungsi untuk konversi torsi dan kecepatan (putaran) dari mesin menjadi torsi dan kecepatan yang berbeda-beda untuk diteruskan ke penggerak akhir. Konversi ini mengubah kecepatan putar yang tinggi menjadi lebih rendah tetapi lebih bertenaga, atau sebaliknya. 


\section{Jurnal Ilmiah FLASH Volume 2 Nomor 2 Desember 2016}

Torsi tertinggi suatu mesin umumnya terjadi pada sekitar pertengahan dari batas putaran mesin yang diijinkan, sedangkan kendaraan memerlukan torsi tertinggi pada saat mulai bergerak. Selain itu, kendaraan yang berjalan pada jalan yang mendaki memerlukan torsi yang lebih tinggi dibandingkan mobil yang berjalan pada jalan yang mendatar. Kendaraan yang berjalan dengan kecepatan rendah memerlukan torsi yang lebih tinggi dibandingkan kecepatan tinggi. Dengan kondisi operasi yang berbeda-beda tersebut maka diperlukan sistem transmisi agar kebutuhan tenaga dapat dipenuhi oleh mesin.

Transmisi diperlukan karena mesin pembakaran yang umumnya digunakan dalam mobil merupakan mesin pembakaran internal yang menghasilkan putaran (rotasi) antara 600 sampai $6000 \mathrm{rpm}$. Sedangkan, roda berputar pada kecepatan rotasi antara 0 sampai $2500 \mathrm{rpm}$.

Sekarang ini, terdapat dua sistem transmisi yang umum, yaitu transmisi manual dan transmisi otomatis. Terdapat juga sistemsistem transmisi yang merupakan gabungan antara kedua sistem tersebut, namun ini merupakan perkem-bangan terakhir yang baru dapat ditemukan pada mobil-mobil berteknologi tinggi dan merek-merek tertentu saja.

b.Pengertian Transmisi Manual

Transmisi manual adalah sistem transmisi otomotif yang memerlukan pengemudi sendiri untuk menekan/menarik seperti pada sepeda motor atau menginjak kopling seperti pada mobil dan menukar gigi percepatan secara manual. Gigi percepatan dirangkai di dalam kotak gigi/gerbox untuk beberapa kecepatan, biasanya berkisar antara 3 gigi percepatan maju sampai dengan 6 gigi percepatan maju ditambah dengan 1 gigi mundur (R). Gigi percepatan yang digunakan tergantung kepada kecepatan kendaraan pada kecepatan rendah atau menanjak digunakan gigi percepatan 1 dan seterusnya kalau kecepatan semakin tinggi, demikian pula sebaliknya kalau mengurangi kecepatan gigi percepatan diturunkan, pengereman dapat dibantu dengan penurunan gigi percepatan.

c. Transmisi Otomatis

Transmisi Otomatis atau Automatic Transmission atau CVT yang lengkapnya adalah continuously variable transmission, merupakan salah satu sistem pemindah tenaga otomatis yang banyak digunakan saat ini. Perbedaan dasar CVT dibandingkan dengan pemindah tenaga lain, seperti transmisi otomatis konvensional dan manual, Pada CVT tidak lagi digunakan roda-roda gigi untuk menurunkan atau menaikkan putaran ke roda. Sebagai penggantinya, digunakan dua puli dan sabuk logam. Karena tidak ada lagi roda-roda gigi, maka pada CVT tidak ada perbandingan gigi seperti transmisi otomatis konvensional dan manual. Transmisi disinipun beda halnya dengan transmisi dalam bidang telekomunikasi. Walaupun pada hakikatnya memiliki pemahaman yang sama,yaitu "menyalurkan". Jika pada bidang telekomunikasi istilah transmisi dapat diartikan 'menyalurkan informasi', sedangkan pada bidang Mekanik atau Otomatif, transmisi dapat diartikan 'menyalurkan gaya'. Istilah Automatic Transmission (AT) dan Manual Transmission (MT).

\section{d.Roda Gigi}

Roda gigi digunakan untuk mentransmisikan daya besar dan putaran yang tepat. Roda gigi memiliki gigi di sekelilingnya, sehingga penerusan daya dilakukan oleh gigi-gigi kedua roda yang saling berkait. Roda gigi sering digunakan karena dapat meneruskan putaran dan daya yang lebih bervariasi dan lebih kompak dari pada menggunakan alat transmisi yang lainnya, selain itu roda gigi juga memiliki beberapa kelebihan jika dibandingkan dengan alat transmisi lainnya, yaitu :

$\square$ Sistem transmisinya lebih ringkas, putaran lebih tinggi dan daya yang besar. 
$\square$ Sistem yang kompak sehingga konstruksinya sederhana.

$\square$ Kemampuan menerima beban lebih tinggi.

$\square$ Efisiensi pemindahan dayanya tinggi karena faktor terjadinya slip sangat kecil.

Kecepatan transmisi roda gigi dapat ditentukan sehingga dapat digunakan dengan pengukuran yang kecil dan daya yang besar. Roda gigi harus mempunyai perbandingan kecepatan sudut tetap antara dua poros. Di samping itu terdapat pula roda gigi yang perbandingan kecepatan sudutnya dapat bervariasi. Ada pula roda gigi dengan putaran yang terputus-putus.

\section{METODOLOGI}

1). Bagan Alir Penelitian

Penelitian ini merupakan hal yang baru di NTT dan di Politeknik Negeri Kupang khususnya. Untuk lebih jelas dapat ditunjukan melalui Gambar 7. diagram alir (Fish bone) penelitian.

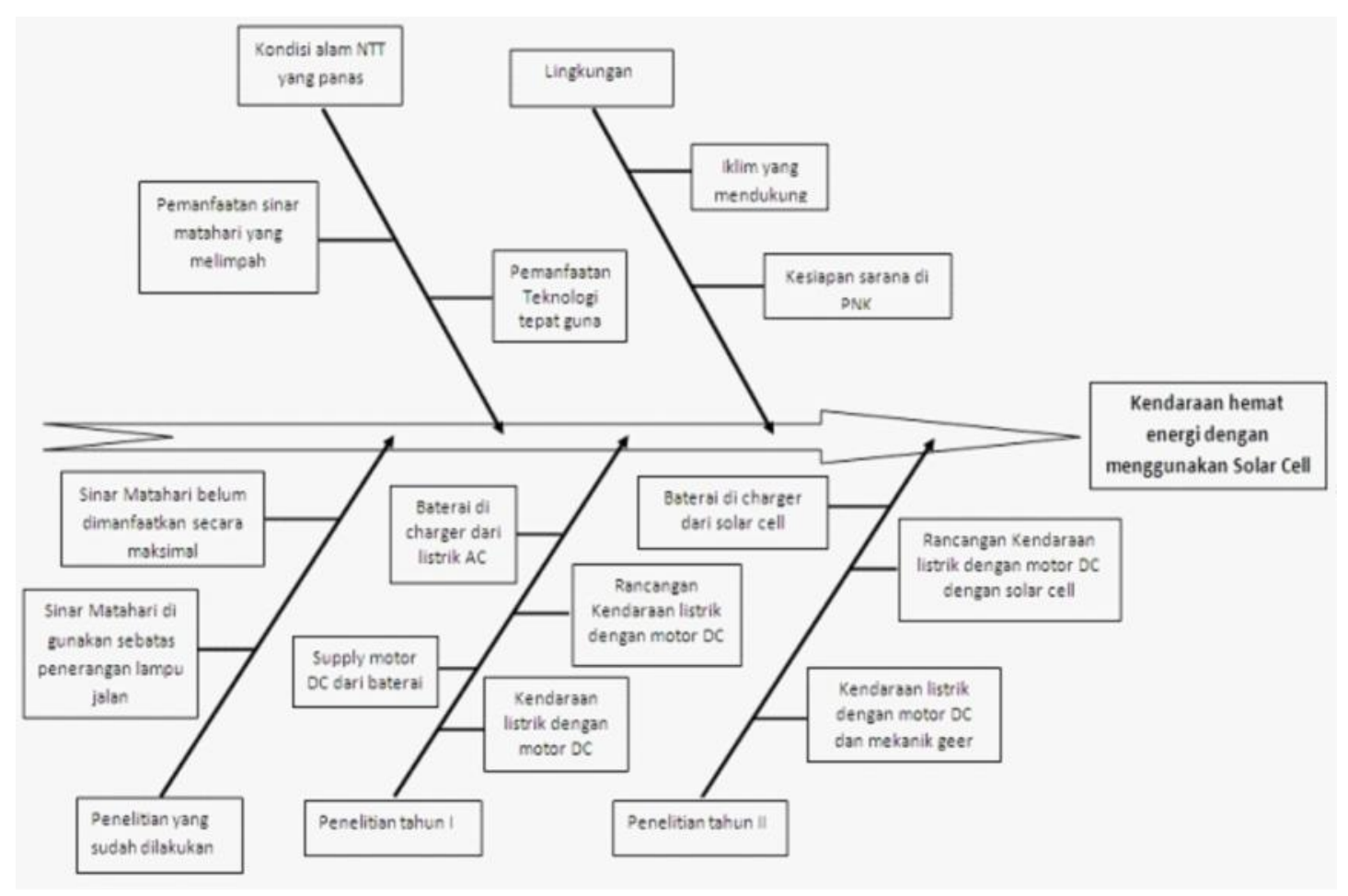

2). Tahapan Penelitian

Penelitian ini dilaksanakan dalam 2 tahun dengan beberapa tahapan, untuk lebih jelas dapat ditunjukkan pada Gambar 8 dan 9 bagan alir tahapan penelitian. 


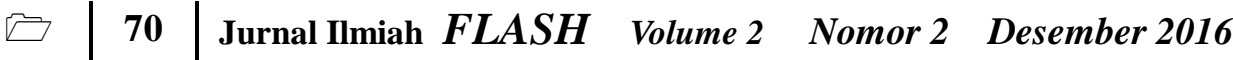

Penelitian Tahun 1 :

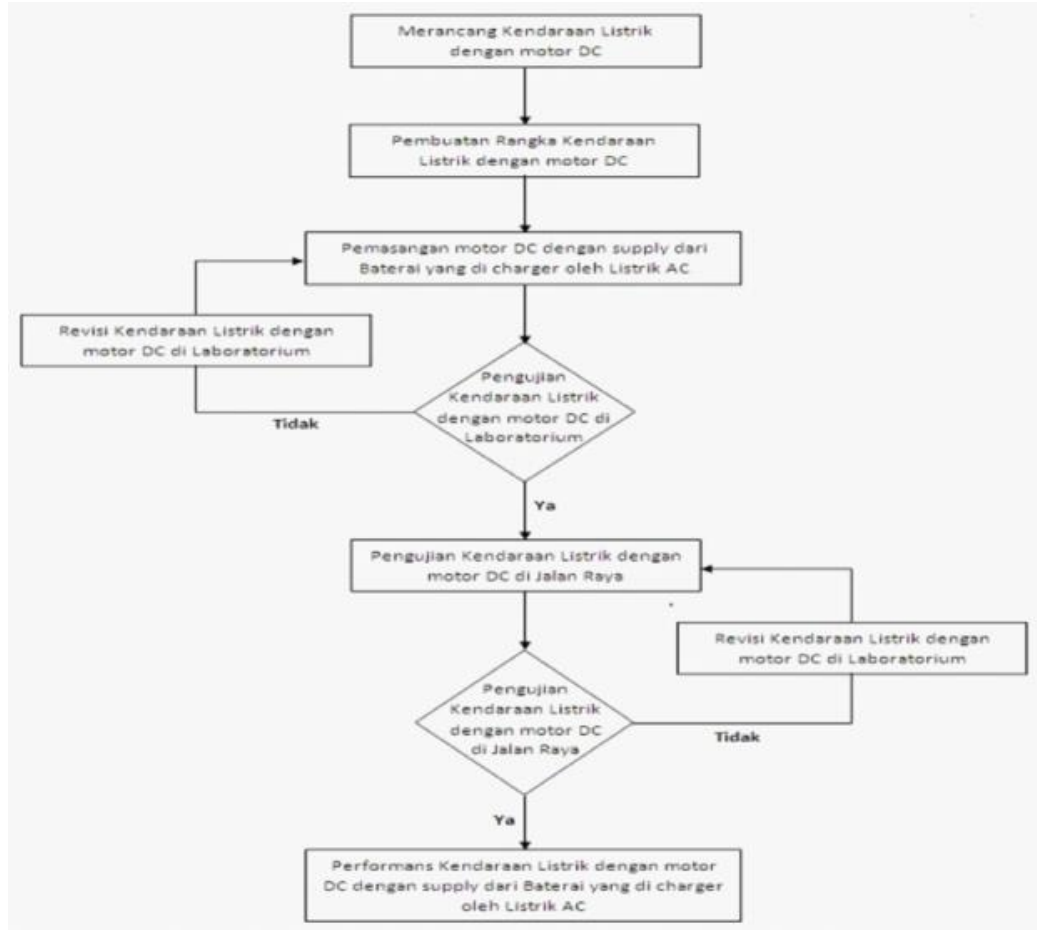

Penelitian Tahun II

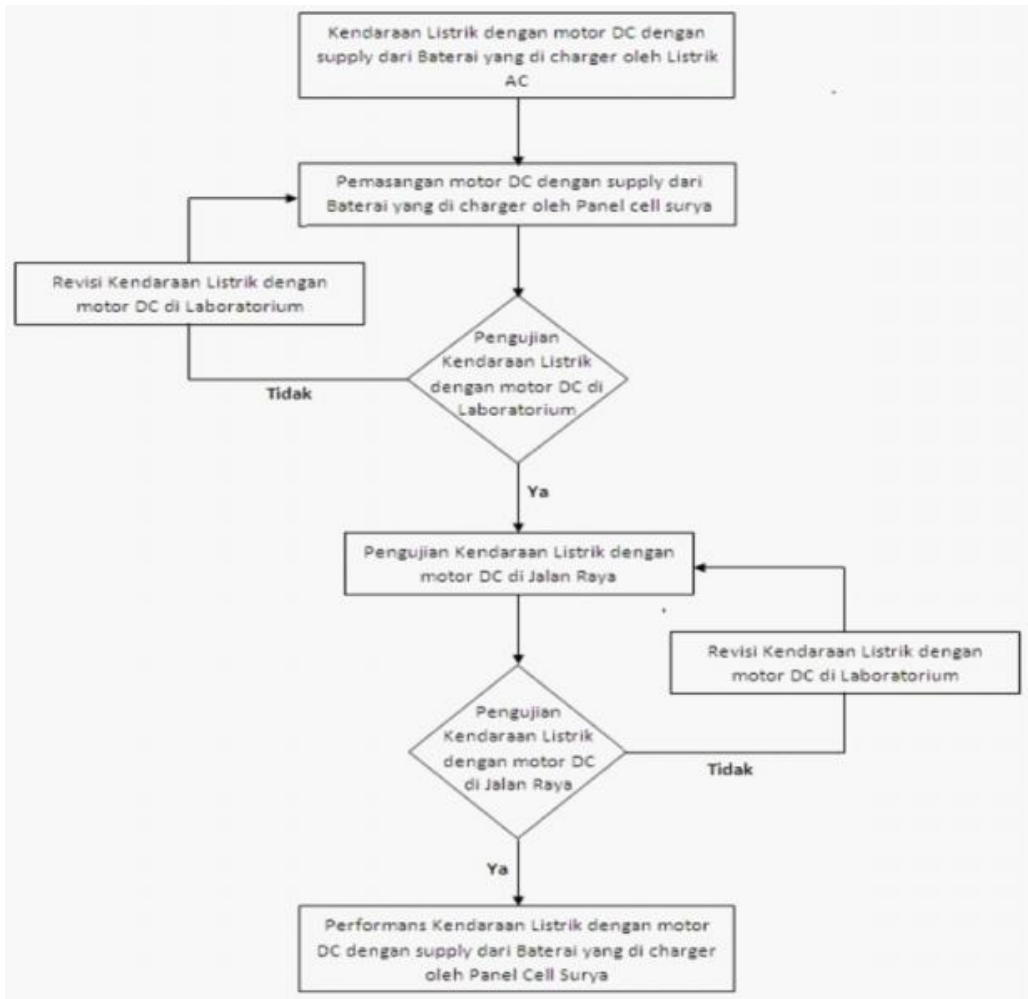


3). Tahapan, Indikator Capaian dan Luaran Penelitian

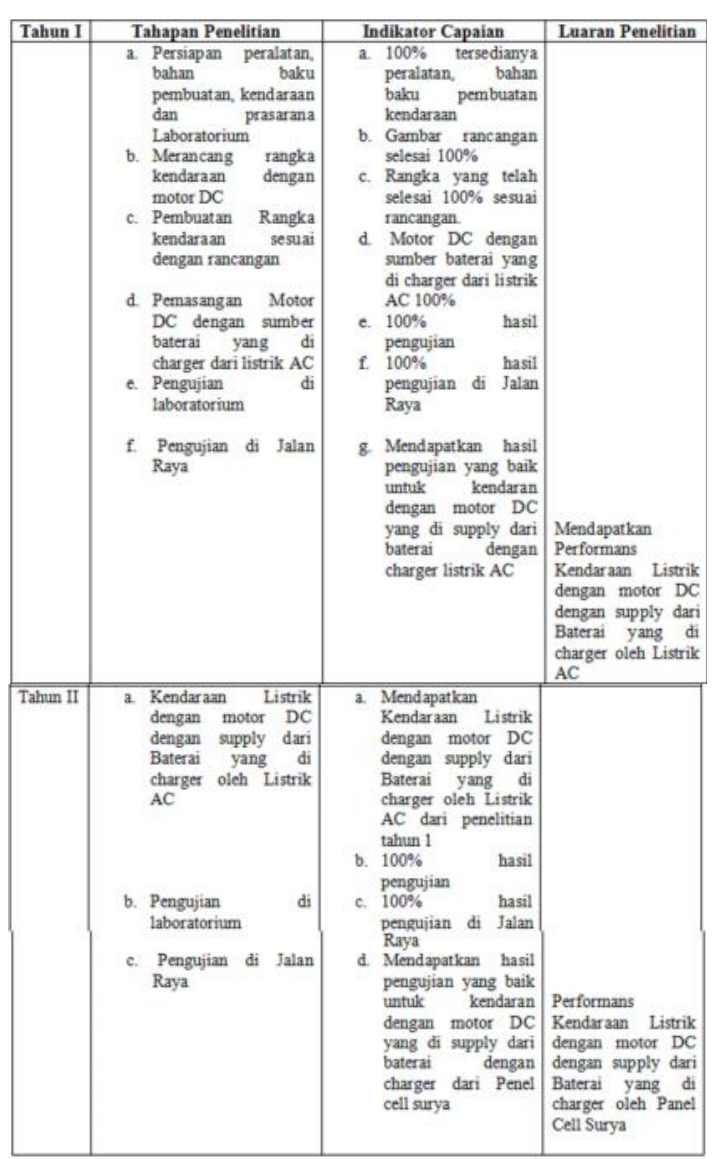

\section{HASIL DAN PEMBAHASAN}

Kendaraan listrik yang dibuat ini pada tahap pembuatanya secara umum sama dengan pembuatan pada kendaraan lain umumnya yaitu terdapat beberapa langkah yang harus diperhatikan seperti;

1). Perancangan rangka kendaraan

Perancangan Rangka Kendaraan

a.Perancangan Kendaraan Motor Listrik (Kendaraan) dengan tenaga listrik DC (direct current) dan sistem transmisi geer mekanik. Dengan hasil sementara adalah sebagai berikut. Pada tahap ini dirancang rangka kendaraan yang sesuai dengan keperluan untuk dua penumpang dengan beban antara $300-500 \mathrm{Kg}$, pada tahap ini rancangan kendaraan dapat dilihat pada gambar 10 di bawah ini.

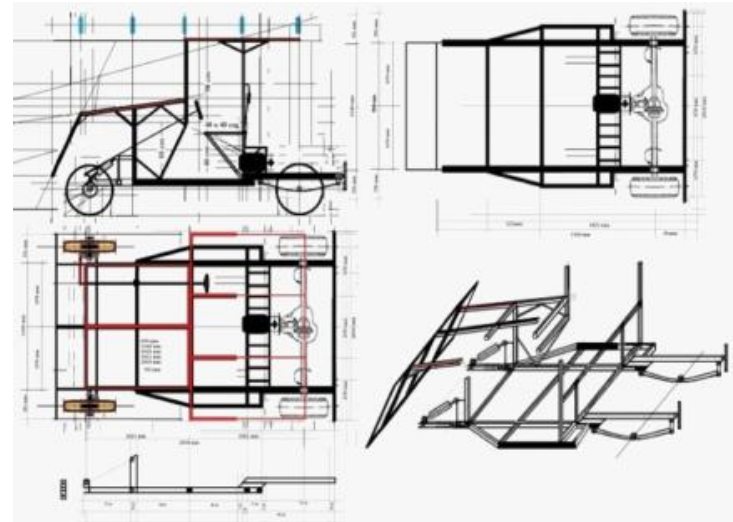

Gambar 10. Gambar BiAwak PNK NTT

Pada gambar 1 kendaraan ini diberi nama BiAwak PNK NTT maksudnya adalah kendaraan listrik dengan 2 (dua $=$ Bi) orang awak (penumpang) dari Politeknik Negeri Kupang (PNK) karena ini baru pertama kali dilakukan penelitian dan pembuatanya di Kupang - Nusa Tenggara Timur (NTT). Dengan arti yang lain yaitu melestarikan nama hewan yang tergolong langka yaitu biawak yang merupakan binatang asli dari NTT selain komodo yang harus dilestarikan karena diprediksi sudah hampir punah.

b. Pembuatan Chasis

Kendaraan listrik ini direncanakan memiliki panjang $\pm 280 \mathrm{~cm}$ dan lebar 210 $\mathrm{cm}$, panjang dan lebar kendaraan BiAwak ini didapat berdasarkan panjang dari 2 buah panel solar cell $100 \mathrm{wp}$ yang direncanakan tersusun 2 dibagian depan dan 3 dibagian atas yang berwungsi sebagai atap jadi jumlah panel cell surya yang digunakan 5 buah (500 wp), sedangkan lebar juga diperoleh dari lebar panel cell surya 100 wp $\pm 670 \mathrm{~cm}$, sehingga bila disusun tiga buah diperoleh lebar $210 \mathrm{~cm}$.

Tinggi kendaraan listrik direncanakan $\pm 163 \mathrm{~cm}$ dari permukaan tanah dengan perincian sebagai berikut; tinggi tempat duduk dari rangka kendaraan (chasis) $40 \mathrm{~cm}$ dan dari tempat duduk ke 


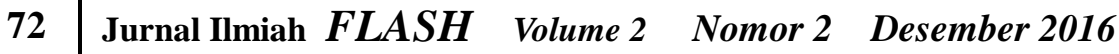

atap kendaraan $90 \mathrm{~cm}$ sedangkan jarak antara chasis dengan permukaan tanah tergantung dari poros roda dan jari-jari roda yang diperkirakan $\pm 33 \mathrm{~cm}$.

\section{c. Sistem Suspensi Belakang}

Sistem suspensi terdiri dari 2 komponen utama yaitu pegas (spring) dan shock absorber, sementara komponen lainnya yaitu suspension arm, ball joint, bushing karet, strut bar, stabilizer bar, bumper dan lain sebagainya. Setiap mobil mungkin berbeda-beda, tetapi pasti ada komponen utamanya yaitu pegas dan shock absorber.

Fungsi pegas pada sistem suspensi adalah untuk menyerap kejutan dari permukaan jalan dan getaran roda-roda agar tidak diteruskan ke body kendaraan. Sedangkan fungsi shock absorber adalah meredam oskilasi naik turun yang diakibatkan oleh pegas. Jika suspensi tanpa shock absorber dan hanya menggunakan pegas saja maka kendaraan akan mentul-mentul dan tidak nyaman untuk di kendarai.

Salah satu fungsi sistem suspensi adalah mencegah oskilasi bodi terjadi pada kendaraan tersebut, ada beberapa macam oskilasi bodi kendaraan yaitu : Pitching, Rolling, Bouncing dan Yawing.

Terdapat dua macam sistem suspensi, yaitu sistem suspensi rigid (dependent) dan sistem suspensi independent. Sistem suspensi rigid banyak digunakan pada mobil-mobil angkutan (niaga) seperti truck, bus, colt, dan lain sebagainya. Sedangkan sistem suspensi independent banyak digunakan pada kendaraan penumpang, sebagai contoh adalah sedan. Hal ini dikarenakan suspensi independent memiliki tingkat kenyamanan yang lebih baik dari pada suspensi rigid

Suspensi bagian belakang direncanakan menggunakan per daun dari jenis kendaraan pickup seperti gambar 11. Agar per tersebut dapat berfungsi sebagaimana suatu sistem suspensi per daun konvensional seperti di perlihatkan pada gambar
12, maka pada chasis diperlukan dudukan per berupa kait statis dan kait dinamis yang padanya terdapat anting agar per dapat bergerak dinamis.

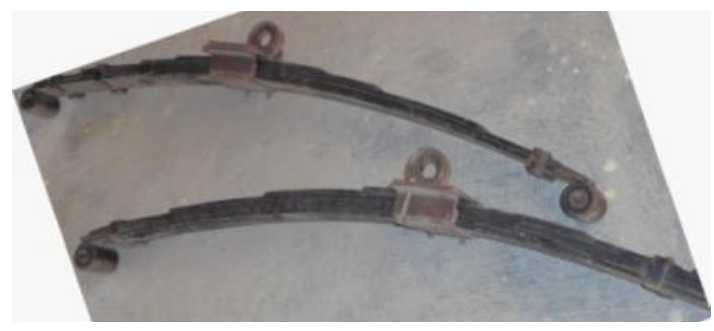

Gambar 11. Per daun

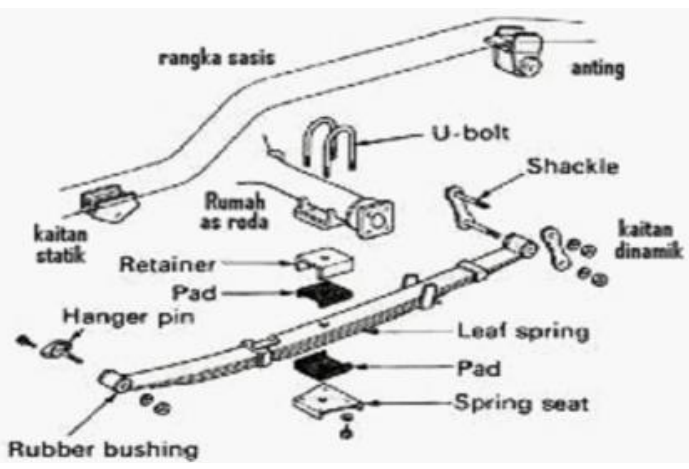

Gambar 12. Konstruksi Dasar Suspensi Konvehsional (per daun)

Dari gambar 12 juga terlihat diperlukannya baut "U" untuk mengikat poros rumah as roda dengan per poros tengah per daun, agar per dapat berfungsi dengan baik diperlukan juga busch untuk penahan baut pada kait statik maupun kait dinamik sehingga per berfungsi saat tejadi guncangan.

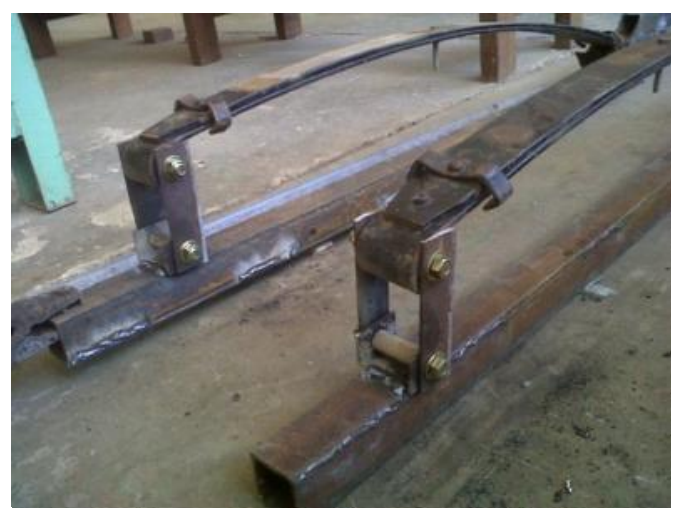

Gambar 13. Pemasangan Kait statis pada chasis 
Hasil pemasangan kait statik maupun kait dinamik dapat dilihat pada gambar 13, maka langkah selanjutnya melakukan pemasangan rangka chasis yang telah jadi pada gardan (gardan bekas dari mobil avanza) untuk mengikatnya menggunakan baut "U" serta membuat dudukan gardan agar terikat sempurna pada rangka chasis. Fungsi utama gardan adalah membedakan putaran roda kiri dan kanan pada saat mobil sedang membelok. Hal itu dimaksudkan agar mobil dapat membelok dengan baik tanpa membuat kedua ban menjadi slip atau tergelincir. Pada saat mobil berjalan lurus keadaan kedua ban roda kiri dan kanan sama-sama dalam kecepatan putaran yang sama, pada saat mobil sedang membelok beban yang ditanggung pada roda bagian dalam adalah lebih besar dari pada beban yang ditanggung roda bagian luar. Misalkan sebuah mobil sedang belok ke kiri, maka beban pada roda kiri akan lebih besar dari pada beban roda kanan Gaya perlawanan dari side gear kiri ini akan membuat pinion gear menjadi berputar mengitari side gear kiri. Dengan berputarnya pininon gear, maka side gear kanan akan diputar oleh pinion gear. Sehingga side gear kanan akan berputar lebih cepat dari side gear kiri. Gerakan side gear ini akan diteruskan ke as roda kemudian ke roda. Untuk roda kanan akan berputar lebih cepat dari pada roda kiri karena side gear kanan berputar lebih cepat.

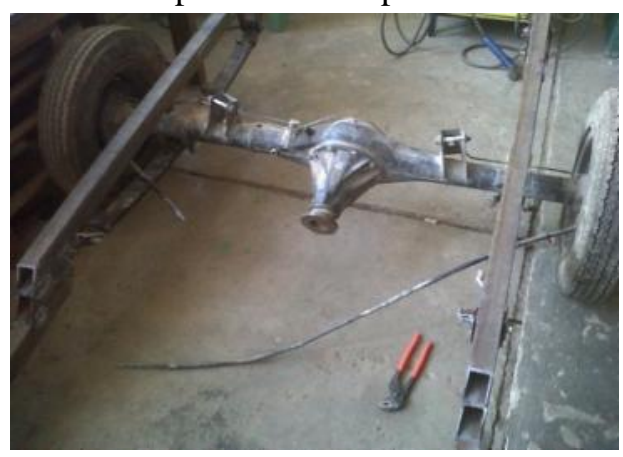

Gambar 14. Rangka chasis yang terpasang pada gardan

\section{d.Suspensi Roda Depan}

Suspensi roda bagian depan menggunakan sistem lengan ayun (swing arm) seperti pada kendaraan roda dua Gambar 15, dengan menggunakan shock absorber motor.

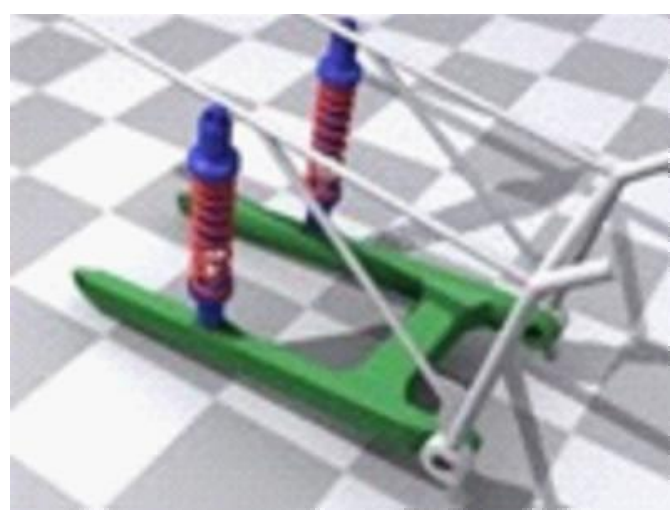

Gambar 15. Lengan Ayun (swing arm)

Dari gambar perencanaan (gambar 1), suspensi roda depan dengan sisitem lengan ayun (swing arm), berikut adalah gambar hasil yang telah dicapai berdasarkan perencanaan tersebut, dengan menggunakan sebuah garpu belakang motor yang dipotong menjadi 2 bagian sehingga satu bagian untuk sisi kiri dan yang lain untuk sisi kanan agar mempunyai gerakan mekanis yang sama maka poros hasil pemotongan di sambung dengan besi profil.

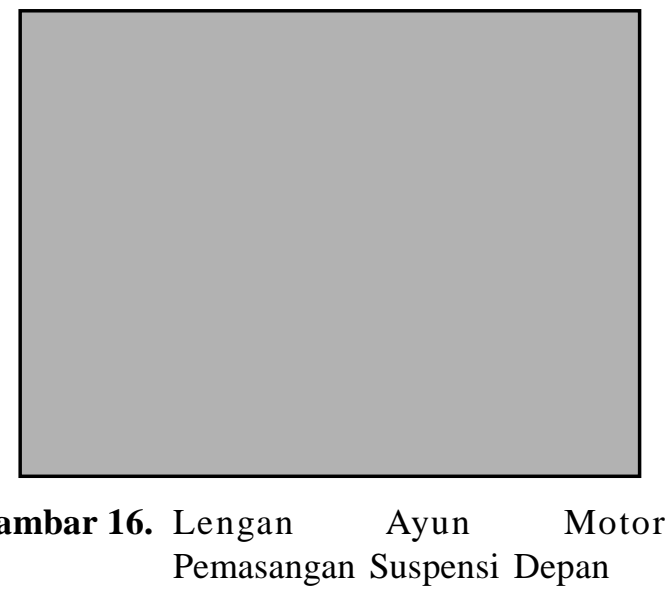


Roda depan kendaraan direncanakan menggunakan roda depan motor jenis yamaha metic dengan ukuran roda $17 \mathrm{x}$ $25 \mathrm{~mm}$ dan poros tunggal yang terhubung dengan sistem mekanik stir dari kendaraan. Pembuatan mekanisme roda depan dan stir diawali dengan mendesain, mengukur, memotong, mengelas bahan berupa besi frofil "L" yang digabung las sehingga membentuk profil "U" dengan menambahkan bosc dan baut nomor 19 .

Salah satu komponen sistem suspensi adalah stabilizer bar, walaupun tidak semua kendaraan atau mobil memiliki stabilizer bar. Stabilizer Bar mempunyai fungsi untuk mengurangi kemiringan mobil yang disebabkan oleh gaya sentrifugal ketika mobil membelok.

2). Jenis motor penggerak dan daya motor

Motor yang digunakan jenis dc yaitu BLDC motor dengan daya 750 watt dengan tegangan 48 volt sehingga diperlukan 4 buah accu 12 volt yang terhubung secara seri.

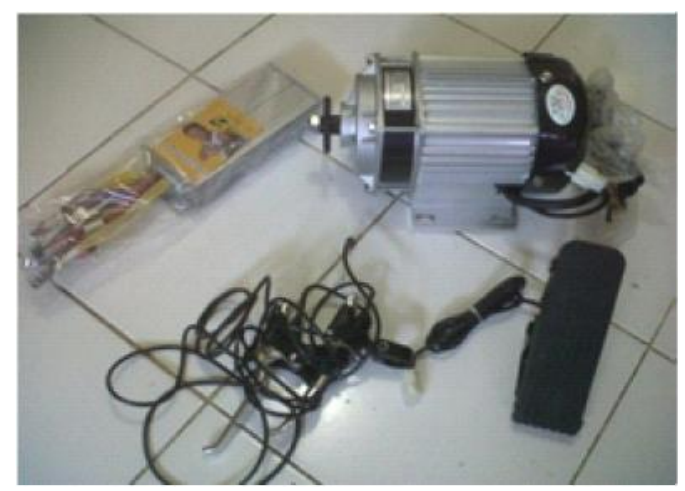

Gambar 17. Motor BLDC 750w 48v

3). Kemudi atau Stir (steering)

Pada kendaraan sistem kemudi (steering system) berfungsi untuk mengatur arah dari kendaraan, dengan cara membelokkan roda depan. Ada juga beberapa kendaraan yang membelokkan dengan roda belakang seperti carlift. Tetapi pada umumnya untuk kendaraan jenis penumpang adalah dengan membelokkan roda depan. Sistem kemudi dibedakan menjadi dua yaitu :
a)Sistem kemudi secara manual

b)Sistem kemudi daya (power steering).

Pada penelitian ini sistem kemudi yang digunakan masih menggunakan sistem kemudi secara manual seperti terlihat pada gambar 18 .

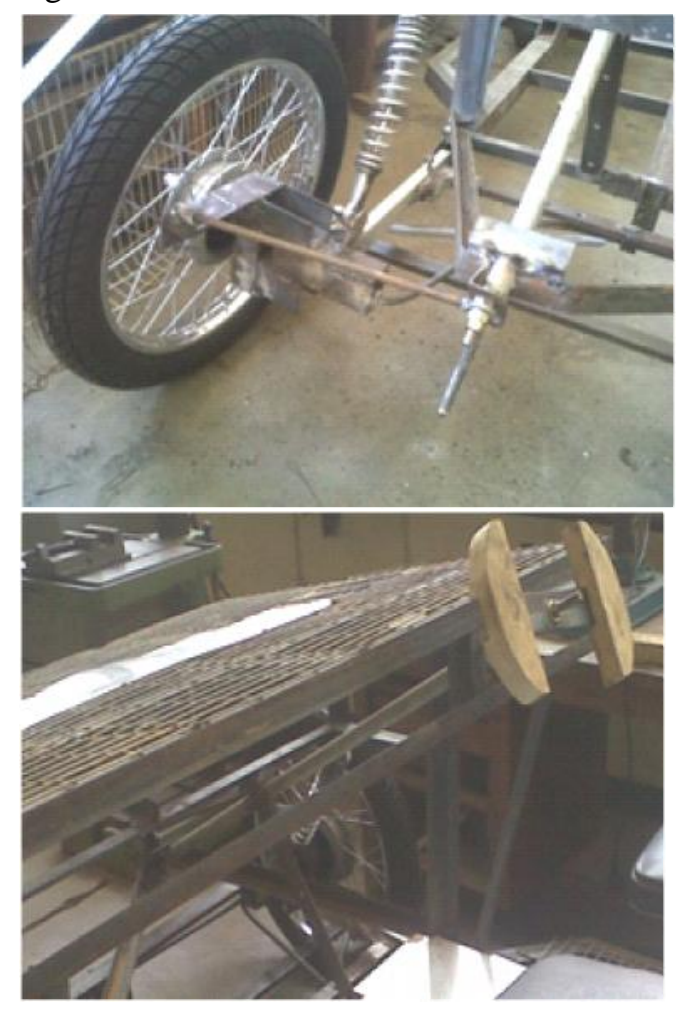

Gambar 18. Sistem Kemudi Manual

5). Tempat Duduk (Jok)

Jok adalah tempat duduk bantalan yang berfungsi menopang tubuh dan peredam guncangan. Umumnya istilah Jok digunakan pada tempat duduk kendaraan bermotor. Istilah jok dalam bahasa Indonesia juga dapat diartikan kursi rumah yang terbuat dari busa. jok berbahan busa adalah model yang sering dipakai karena busa termasuk bantal peredam terbaik.

6). Spesifikasi Kendaraan

Spesifikasi Dinamo ;

Jenis Dinamo: BLCD

Daya : 750 watt 


\begin{tabular}{|c|c|c|}
\hline Tegangan & \multicolumn{2}{|c|}{ : 48 volt } \\
\hline Arus & \multicolumn{2}{|c|}{ : 15 - 16 Ampere } \\
\hline Torsi & \multicolumn{2}{|c|}{$: 480 \mathrm{Nm}$} \\
\hline Controller & \multicolumn{2}{|c|}{$: 1.000$ watt } \\
\hline \multicolumn{3}{|c|}{ Spesifikasi Kendaraan ; } \\
\hline Accu & \multicolumn{2}{|c|}{ : 4 x 12 volt-50 Ah GS } \\
\hline \multicolumn{2}{|c|}{ Empat) } & \\
\hline Suspensi Dep & pan & : Swing Arm \\
\hline Suspensi Bel & lakang & : Per daun \\
\hline Kemudi & & : Manual \\
\hline Radius Putar & & $: 32^{\mathrm{O}}$ \\
\hline Roda Depan & & $\begin{array}{l}: 25-17 \text { (speda } \\
\text { motor) mengguna- } \\
\text { kan ruji }\end{array}$ \\
\hline Roda Belakaı & & : $5.60-30$ (rongsok) \\
\hline Mekanik geeı & & $\begin{array}{l}\text { Gardan Avanza } \\
\text { (rongsokan) }\end{array}$ \\
\hline Jarak Sumbu & oda & $: 200 \mathrm{~cm}$ \\
\hline Ground Cle & nce & $: 23 \mathrm{~cm}$ \\
\hline
\end{tabular}

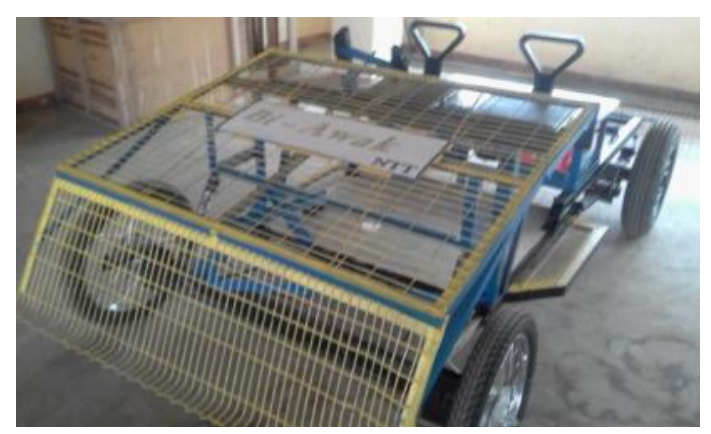

Gambar 19. Kendaraan Listrik "Bi-Awak NTT"

\section{KESIMPULAN DAN SARAN}

\subsection{Kesimpulan}

Kegiatan penelitian tahun I (pertama) sudah dilakukan dengan pencapaian $100 \%$, mulai perancangan sampai dengan tahap pembuatan rangka utama khususnya bagian belakang kendaraan, tempat duduk, rem, stir, kontrol motor, dengan melakukan perakitan semua komponen pelengkap seperti pembuatan suspensi roda depan, perakitan motor dan kontronya Serta pengujian jalan kendaraan di laboratorium mekanik Teknik Elektro PNK.

Dari kegiatan penelitian dan diskusi dengan anggota kolompok disepakati memberi nama
"Bi-Awak NTT" dengan tujuan melestarikan nama binatang yang hampir punah di NTT yaitu Biawak, selain itu juga mempunyai arti Kendaraan yang dapat di muati oleh 2 orang (bi $=2$; awak = badan/anggota) serta akan dilakukan beberapa modifikasi terhadap rancangan sebagai langkah efisiensi waktu dan dana yang digunakan.

\subsection{Saran}

1). Masih banyak terdapat kekurangan yang akan disempurnakan yaitu jangkauan stir yang relatif lebar.

2). Poros dinamo dan gardan yang belum $100 \%$ lurus.

3). Rem yang belum berfungsi sempurna.

\section{DAFTAR PUSTAKA}

Arikunto Suharsimi, Prof., 2002, Prosedur Penelitian (Suatu Pendekatan Praktek), Rineka Cipta, Jakarta.

Beiser A., 1981, Perpectives of Modern Physics, Mc Graw Hill, New York.

Cheremisinoff P. N. and Regino T. C., Principles and Aplication of Solar Energy, Ann Arbor Science Publishers, Inc. Michigan.

Culp A. W. Jr., 1985, Prinsip-prinsip Konversi Energi, Erlangga, Jakarta.

Dixon A. E. and Lestie J. D., 1978, Solar Energy Conversion, Permagon Press, New York.

Ellis R. and Guilick D., 1994, Calculus Analytic Geometry, Harcourt Brace College Publisher, New York.

Krane K., 1992, Fisika Modern, Penerbit Universitas Indonesia, Jakarta. 